\title{
Availability of small indigenous species (SIS) of fish in the Chalan Beel - the largest wetland of Bangladesh
}

Fahmida Akhter Kostori, Selina Parween ${ }^{1}$ and M Nazrul Islam ${ }^{1}$

Institute of Environmental Science, University of Rajshahi, Rajshahi - 6205, Bangladesh.

${ }^{1}$ Department of Zoology, University of Rajshahi, Rajshahi - 6205, Bangladesh

\begin{abstract}
An investigation was conducted to study the abundance and diversity of Small Indigenous Species (SIS) of fish in the Chalan Beel. Sampling was carried out frequently over a year in selected landing centres, fish markets and catch points. A total of 82 SIS fish belonging to 10 orders, 22 families and 46 genera were recorded. The order Cypriniformes $(42.68 \%)$ was the most dominant order comprising 35 species. The most dominant family of the order Cypiniformes was Cyprinidae (77.14\%) comprising 27 species, and Puntius was the largest genus including 7 species. The most abundant SIS fishes observed during the study period were Tengra (Mystus vittatus, M. tengara), Punti (Puntius sophore and P. ticto), Taki (Channa punctatus), Guchi Baim (Mastacembelus pancalus), and the least abundant SIS fish were Aplocheilus panchax, Badis badis, Danio sp. and Chaca chaca. Availability of the species were ranked as Few $(39 \%)$, followed by Common $(23 \%)$, Very Common $(15 \%)$, Rare $(16 \%)$ and Very Rare $(7 \%)$. At Mohisluti fish landing centre (under Tarash, Sirajganj) the highest number of species $(79,96.34 \%)$ of small fishes were found. Abundance of different SIS fishes were found to vary with the season.
\end{abstract}

Key Words: Availability, SIS fish, Chalan Beel, Wetland.

\section{Introduction}

Chalan Beel, the largest beel in Bangladesh, is the low-lying wetland area between the Barind tract and the Ganges river flood plains (Uddin, 2002). It is located between $24^{\circ} 05^{\prime}$ to $24^{\circ} 35^{\prime}$ North latitude and $89^{\circ}$ to $89^{\circ} 35^{\prime}$ East longitude. The beel extends over the adjacent districts of Naogaon, Natore, Sirajgonj and Pabna. It is the most important watershed in North Western Bangladesh which covers an area of about $375 \mathrm{~km}^{2}$ during monsoon season and $52-78 \mathrm{~km}^{2}$ during the dry season (Hossain et al., 2009). There are 260 species of fresh water indigenous fin fish in the inland open waters of Bangladesh which are belonging to 55 families (Rahman, 1989). Of these 260 species, over 150 species have been classified as "Small Indigenous Species" (Amin et al., 2009). The small indigenous species (SIS) of fish in Bangladesh are generally considered to be those, which grow to a length of about $25 \mathrm{~cm}$ or 9 inches at maturity (Felts et al., 1996; Hossain \& Afroze, 1991 and Hossain et al., 1999). However, there is some sort of contradiction exist in the above definition because there are some species (viz. Puntius sarana, Clarias batrachus, Channa barca, Xenentodon cancila, Heteropneustes fossilis etc.) which are considered as SIS fish but their size is more than $25 \mathrm{~cm}$. In the Chalan beel 121 species of SIS fish are found including 41 riverine, 29 migratory and 51 flood plain species (Hoq, 2006). SIS fishes have been considered as an excellent source of essential protein, macro- and micronutrients, vitamins and minerals, which can play an important role in the elimination of malnutrition problem in Bangladesh (Hossain \& Afroze, 1991 and Thilsted et al., 1997).
Some SIS fish like Punti (Puntius sp.) contains double the amount of iron compared to many cultured carps like Silver carp (Hypopthalmichthys molitrix) and Rui (Labeo rohita); and Mola (Amblypharyngodon mola) contains three times more calcium and 50 times more vitamin- $A$ than that of Silver carp and Rui (Villif \& Jorgensen, 1993). These small fishes are important item in the daily diet of the people of all categories. Majority of the people of Bangladesh has no choice but to eat different species of small fishes with their staple food rice since they cannot afford to purchase high priced large carp species (Hossain et al., 1994).

The minimum per capita per day protein requirement in Bangladesh is $45.30 \mathrm{~g}$, of which i.e. $15 \mathrm{~g}$ should of animal origin, but the present supply of animal protein is only $5 \mathrm{~g}$ and of which $80 \%$ is contributed by fishes (Jabbar \& Karim, 1979). To meet up animal protein deficiency of the people, greater emphasis should be given to boost up SIS fish production in this country through proper management of open water fishery and aquaculture (Kohinoor, 2000). Before undertaking any fisheries management tools, the fish diversity in the water must be known (Huda et al., 2009). Chalan Beel is famous for its richness in fisheries resources, but there is a lack of published reports on its ichthyofauna and their status. For proper management techniques and biodiversity conservation of SIS fish in the Chalan Beel, it is important to study these factors. This paper describes the diversity of SIS fish and their status in the Chalan Beel. 


\section{Materials and Methods}

The sampling was conducted for a year from September 2010 to August 2011 following the method described by Backiel \& Welcome (1980). To carry out the present study more than 14 spots of the Chalan Beel under 8 upazilas of 4 districts were selected. These spots were Natore sadar, Singra, Baraigram and Gurudaspur of Natore district, Chatmohor and Bhangura of Pabna district, Tarash of Sirajganj district and Atrai of Noagaon district. Survey spots included different fishing spots of the Beel, various fish landing centres and fish market adjacent to Chalan Beel. The study spots were selected in such a way that those spots cover all the major areas of Chalan Beel. Five fish landing centres viz. Singra (Natore), Atrai (Noagaon), Mohisluti (Tarash, Sirajganj), Bhangura and Chatmohor (Pabna) and 9 fish markets: Naldanga, Jonail, Rajapur,

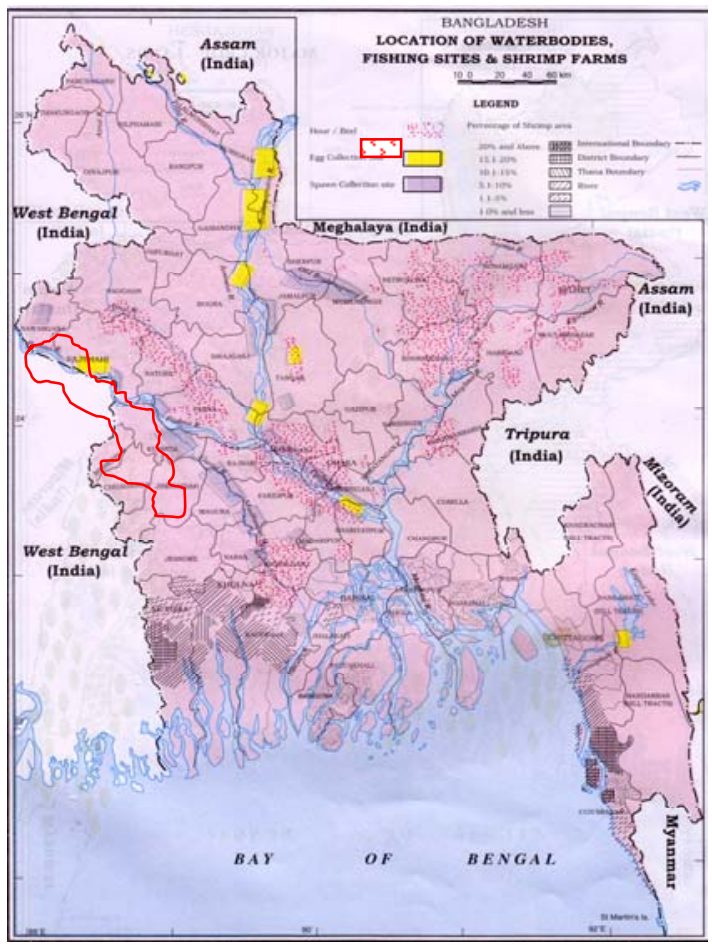

Fig. 1: Showing the study areas of the Chalan Beel
Baraigram, Gurudaspur, Chowgram, Kaliganj, Tarash and Mannannagar and some catch point were selected to collect fish sample and data for this investigation (Fig. $1 \& 2$ ).

Various participatory rural apprisal (PRA) tools like interviews, direct observations and focus group discussions (FGDs) were executed, with the fishermen and fish traders were used to constitute data for this investigation. The samples of SIS fish were primarily sorted out in the collection area with the help of fishermen or fish traders. The samples which were difficult to identify on the spot, were preserved in $10 \%$ formalin and brought to the laboratory of the Institute of Environmental Science, University of Rajshahi, and were identified after Bhuiyan (1964), Rahman (2005), Talwar \& Jhingran (1991) and Fish Base website (www.fishbase.org).

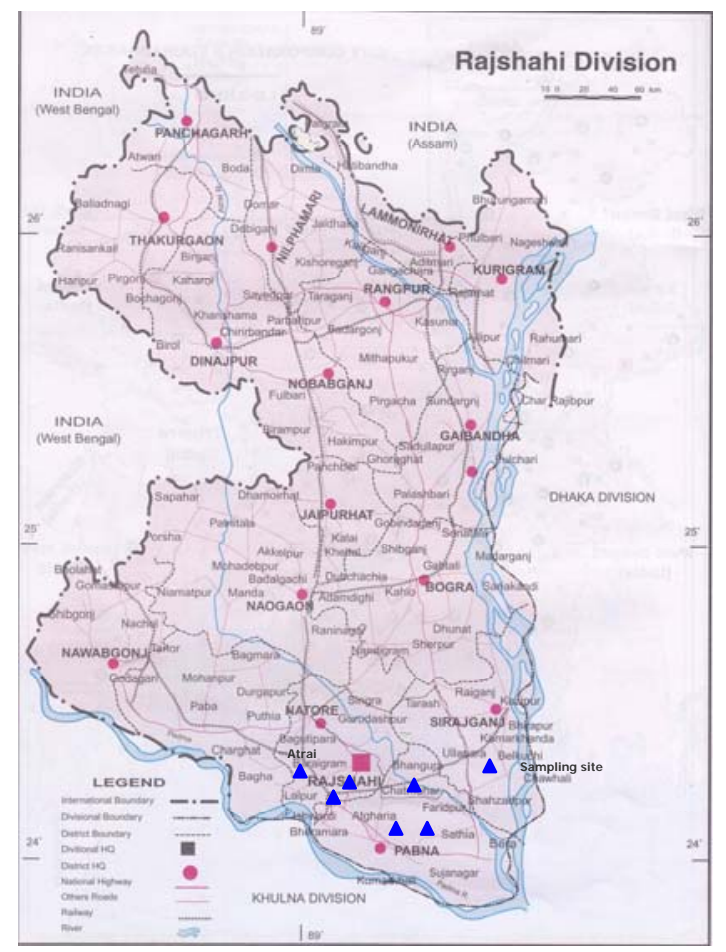

Fig. 2: Sampling sites of SIS fish in the Chalan Beel

Source: Jahan Atlas, Jahan Printing \& Color Process Ltd., Dhaka, January 2009.

\section{Results and Discussion}

Fish Diversity: In the present investigation, 82 small indigenous species of fish were identified under 10 orders, 22 families and 46 genera. The taxonomic features of the identified species are presented in Table 1. The order Cypriniformes
(42.68\%) was the most dominant order comprising 35 species. The highest number of SIS fish (27) was identified under the family Cyprinidae (77.14\%). Puntius was the most dominant genus including 7 species. The result suggested that the water bodies of Chalan Beel were suitable for barbs and minnows. 
Table 1: SIS fish with their occurrence in investigation sites at the Chalan Beel and their seasonal abundance.

\begin{tabular}{|c|c|c|c|c|c|c|c|}
\hline $\begin{array}{l}\text { SI. } \\
\text { no. }\end{array}$ & Order & $\begin{array}{c}\text { Family } \\
\text { (Sub- } \\
\text { family) }\end{array}$ & $\begin{array}{l}\text { Sl. no } \\
\text { of sp. }\end{array}$ & $\begin{array}{l}\text { Scientific Name } \\
\text { (Local Name) }\end{array}$ & $\begin{array}{l}\text { Investigation } \\
\text { sites* }\end{array}$ & $\begin{array}{c}\text { Abun- } \\
\text { dance }\end{array}$ & $\begin{array}{l}\text { Seasona } \\
\text { I availa- } \\
\text { bility }^{\star \star *}\end{array}$ \\
\hline 1. & 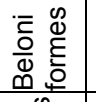 & 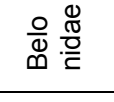 & 1 & Xenentodon cancila (Hamilton, 1822) (Kakila) & At, B, Ch, M, S & C & M \\
\hline \multirow{3}{*}{2.} & \multirow{3}{*}{ 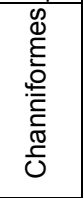 } & \multirow{3}{*}{$\begin{array}{l}\frac{0}{\pi} \\
\frac{\pi}{0} \\
\frac{0}{1} \\
\frac{\pi}{0} \\
\frac{\pi}{0}\end{array}$} & 2 & Channa punctatus (Bloch and Schneider, 1801) (Taki, Sati) & At, B, Ch, M, S & VC & W \\
\hline & & & 3 & $\begin{array}{l}\text { C. orientalis (Bloch and Schneider, 1801) (Chaitan, Gori, Taki, } \\
\text { Sati) }\end{array}$ & At, B, Ch, M, S & C & W \\
\hline & & & 4 & $\begin{array}{l}\text { C. gachua (Hamilton, 1822) (Chaitan, Gori, Cheng, Pagla, Raga, } \\
\text { Hulpa) }\end{array}$ & At, B, Ch, M, S & C & W \\
\hline \multirow{5}{*}{3.} & \multirow{5}{*}{ 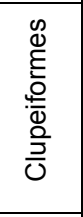 } & \multirow{5}{*}{ 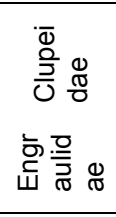 } & 5 & Corica soborna (Hamilton, 1822) (Kachki) & At, B, Ch, M, S & C & PM \\
\hline & & & 6 & Gudusia chapra (Hamilton, 1822) (Chapila) & At, B, Ch, M, S & VC & W \\
\hline & & & 7 & G. variegata (Day, 1889) (Hilsha) & At, B, Ch, M, S & $\mathrm{F}$ & W \\
\hline & & & 8 & Setipinna phasa (Hamilton, 1822) (Phasa) & B, Ch, M, S & $\mathrm{R}$ & M \\
\hline & & & 9 & S. taty (Valenciennes, 1848) (Teli phasa) & B, Ch, M, S & $\mathrm{R}$ & M \\
\hline \multirow{35}{*}{4.} & \multirow{35}{*}{ 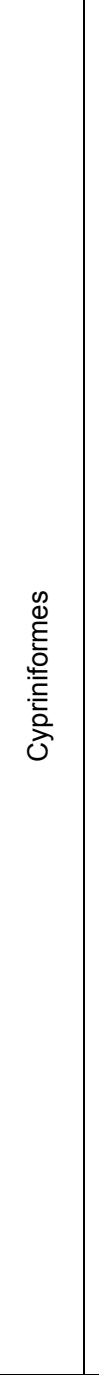 } & \multirow{14}{*}{$\begin{array}{l}\frac{1}{\pi} \\
\frac{\pi}{0} \\
: 0 \\
0 \\
0\end{array}$} & 10 & Botia dario (Hora, 1932) (Bou, Rani) & At, B, Ch, M, S & $\mathrm{F}$ & PM \\
\hline & & & 11 & B. dayi (Hamilton, 1822) (Bou, Rani) & At, B, Ch, M, S & $\mathrm{F}$ & W \\
\hline & & & 12 & B. lohachata (Chaudhuri, 1912) (Putul, Beti) & At, B, Ch, S & $\mathrm{R}$ & A \\
\hline & & & 13 & Lepidocephalichthyes guntea (Hamilton, 1822) (Gutum, Gor Puiya) & At, B, Ch, M, S & VC & A \\
\hline & & & 14 & L. berdmorei (Blyth, 1860) (Punja, Puiya) & At, Ch, M, S & $\mathrm{R}$ & A \\
\hline & & & 15 & Acanthophthalmus pangia (Hamilton, 1822) (Balichata) & At, B, Ch, M, S & $\mathrm{F}$ & A \\
\hline & & & 16 & Nemachilus botia (Hamilton, 1822) (Shavon) & $\mathrm{Ch}, \mathrm{M}$ & $\mathrm{R}$ & M \\
\hline & & & 17 & N. savona (Hamilton, 1822) (Khorka) & At, B, Ch, M & $\mathrm{R}$ & M \\
\hline & & & 18 & Amblypharyngodon mola (Hamilton, 1822) (Mola, Moya) & At, B, Ch, M, S & VC & A \\
\hline & & & 19 & A. microlepis (Bleeker, 1860) (Mola, Moya) & At, B, Ch, M, S & $\mathrm{F}$ & A \\
\hline & & & 20 & Aspidoparia jaya (Hamilton, 1822) (Piale, Jaya, Hiralu) & At, B, Ch, M, S & $\mathrm{F}$ & M \\
\hline & & & 21 & A. morar (Hamilton, 1822) (Morar piale) & At, B, Ch, M, S & $\mathrm{F}$ & M \\
\hline & & & 22 & Cirrhinus reba (Hamilton, 1822) (Rayek, Bhagna, Raikhar) & At, B, Ch, M, S & $\mathrm{F}$ & M \\
\hline & & & 23 & Labeo bata (Hamilton, 1822) (Bata) & At, B, Ch, M, S & $\mathrm{F}$ & M \\
\hline & & $\underset{\mathbb{T}}{\mathbb{0}}$ & 24 & L. gonius (Hamilton, 1822) (Ghani, Gonia, Ghannya) & At, B, Ch, M, S & $\mathrm{F}$ & M \\
\hline & & $\stackrel{00}{\subseteq}$ & 25 & L. boga (Hamilton, 1822) (Bhangon, Bhangon bata) & At, B, Ch, M, S & $\mathrm{F}$ & M \\
\hline & & 힐 & 26 & Osteobrama cotio (Hamilton, 1822) Dhela, Moa, Pathorchata) & At, $M, S$ & VR & M \\
\hline & & u & 27 & Puntius chola (Hamilton, 1822) (Chola punti) & At, B, Ch, M, S & $\mathrm{F}$ & PM \\
\hline & & & 28 & P. conchonius (Hamilton, 1822) (Kanchan punti) & At, B, Ch, M, S & VC & W \\
\hline & & & 29 & P. phutunio (Hamilton, 1822) (Futani punti) & At, B, Ch, M, S & $\mathrm{F}$ & PM \\
\hline & & & 30 & P. sarana (Hamilton, 1822) (Shor punti) & At, B, Ch, M, S & $\mathrm{R}$ & PM \\
\hline & & & 31 & P. sophore (Hamilton, 1822) (Jat punti) & At, B, Ch, M, S & VC & A \\
\hline & & & 32 & P. ticto (Hamilton, 1822) (Tit punti) & At, B, Ch, M, S & VC & A \\
\hline & & & 33 & P. terio (Hamilton, 1822) (Teri punti) & At, B, Ch, M, S & $\mathrm{F}$ & A \\
\hline & & & 34 & Chela cachius (Hamilton, 1822) (Chap chela) & At, B, Ch, M, S & C & PM \\
\hline & & $\underset{\mathbb{D}}{\mathbb{D}}$ & 35 & C. laubuca (Hamilton, 1822) (Kash khaira) & At, B, Ch, M, S & $\mathrm{F}$ & PM \\
\hline & & $\overline{\underline{D}}$ & 36 & Salmostoma bacaila (Hamilton, 1822) (Katari chela) & At, B, Ch, M, S & $\mathrm{F}$ & PM \\
\hline & & $\overline{\mathrm{O}}$ & 37 & S. phulo (Hamilton, 1822) (Phul chela) & At, B, Ch, M, S & C & PM \\
\hline & & & 38 & S. gora (Hamilton, 1822) (Gora chela) & B, Ch, S & $\mathrm{F}$ & PM \\
\hline & & & 39 & Esomus danricus (Hamilton, 1822) (Darika, Darkina) & At, B, Ch, M, S & C & M \\
\hline & & $\underset{\mathbb{\sigma}}{\mathscr{0}}$ & 40 & Rasbora rasbora (Hamilton, 1822) (Leaza darika) & At, B, Ch, M, S & C & M \\
\hline & & 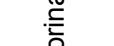 & 41 & R. elanga (Hamilton, 1822) (Elang) & B, Ch, S & $\mathrm{F}$ & M \\
\hline & & $\frac{8}{6}$ & 42 & R. daniconius (Hamilton, 1822) (Darika, Darkina) & At, B, Ch, M, S & VC & M \\
\hline & & $\stackrel{\mathscr{\pi}}{\mathscr{q}}$ & 43 & Danio devario (Hamilton, 1822) (Debri, Chebri) & $M, S$ & VR & M \\
\hline & & & 44 & D. rerio (Hamilton, 1822) (Ranga darika) & $\mathrm{M}, \mathrm{S}$ & VR & M \\
\hline 5. & 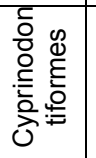 & 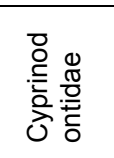 & 45 & $\begin{array}{l}\text { Aplocheilus panchax (Hamilton, 1822) (Kan pona, Pancha chok, } \\
\text { Panchoukha) }\end{array}$ & M & $\mathrm{F}$ & M \\
\hline
\end{tabular}




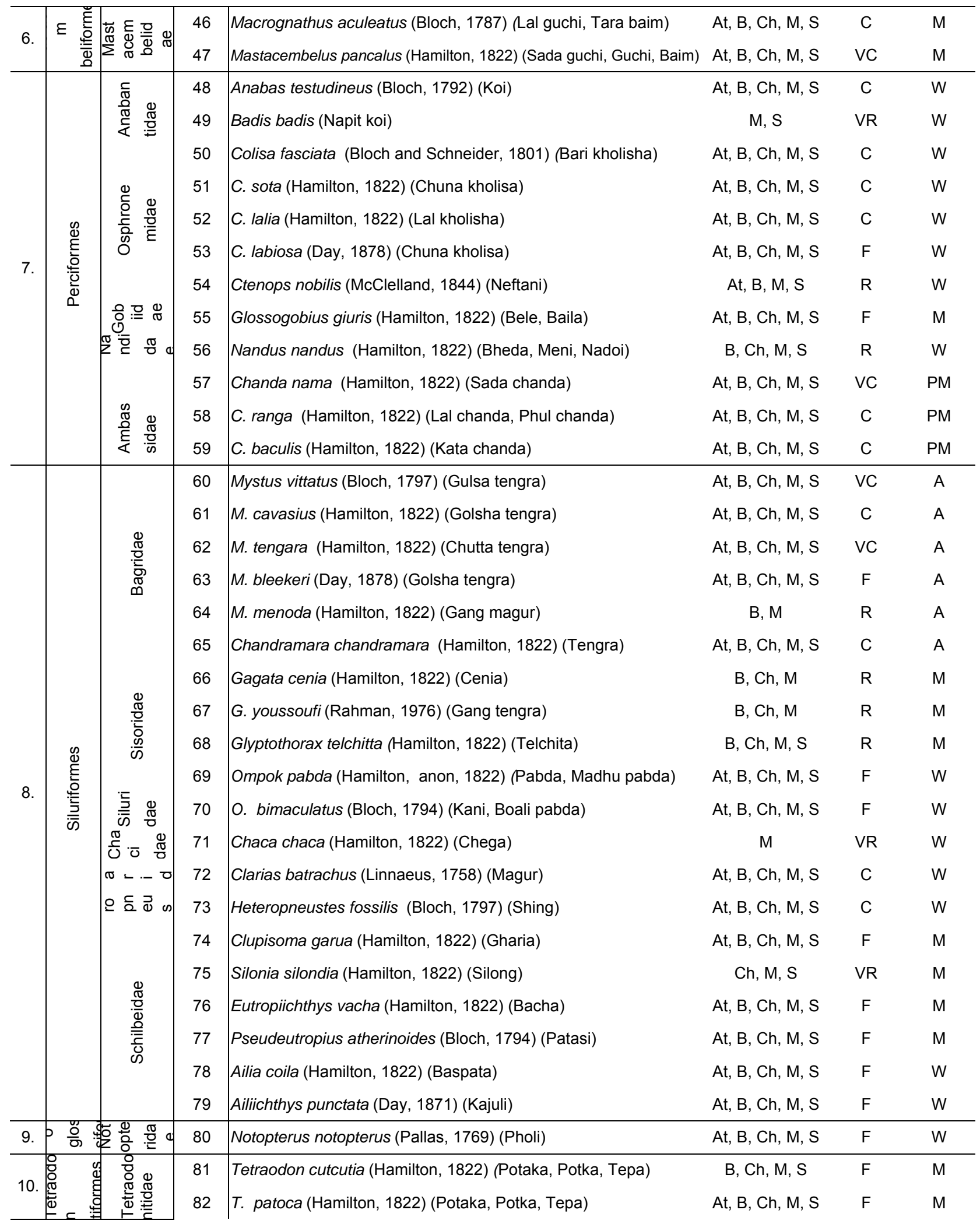

Note: * At $=$ Atrai, $S=$ Singra, $M=$ Mohishluti, $B=$ Bhangura, $C h=$ Chatmohor, $* * V R=$ Very rare $(1-10$ individuals were recorded from specific 1 to 2 study spots), $R=$ Rare (Seldom found species but not very rare, recorded species was 11 to 100 in numbers), $F=$ Few (not very rare or rare but available at a low density and recorded from not more than 12 spots), $C=$ Common (recorded from almost all the study spots and was not so abundant), $V C=V e r y$ common (frequently available species and large amount of catch was made), ${ }^{* * *} \mathrm{M}=$ Monsoon, $\mathrm{PM}=$ Post Monsoon, $\mathrm{A}=\mathrm{All}$ season, $\mathrm{W}=\mathrm{Winter}$. 
A total number of 20 SIS fish was found under the order Siluriformes $(24.39 \%)$ representing the $2^{\text {nd }}$ largest order of SIS fish in the Chalan Beel. Only one species was found under each of the orders Beloniformes, Cyprinodontifomes and Osteoglossiformes. The number of SIS fish found under different orders during the investigation period is shown in Fig. 3.

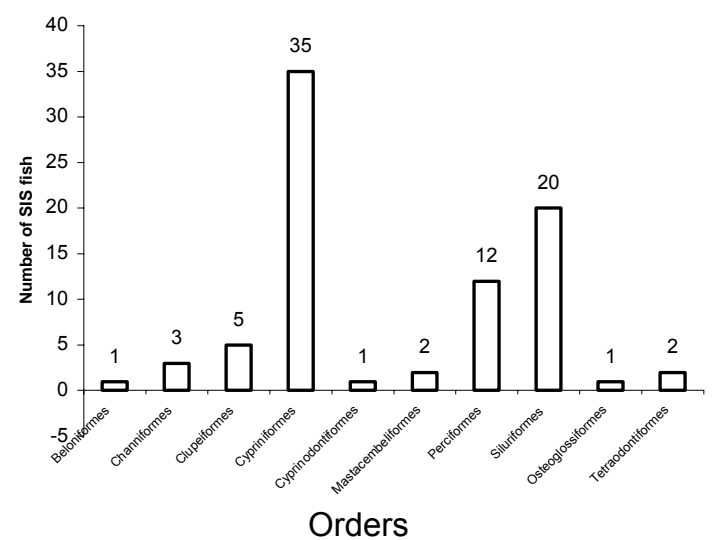

Fig. 3: Number of SIS fish found under different orders during the investigation.

Abundance and Status: Mystus vittatus, M. tengra, Puntius sophore, P. ticto, Channa punctatus, Amblypharyngodon mola, Lepidocephalichthys guntea and Mastacembelus pancalus were the highest available SIS fish during the investigation period in terms of their quantity and seasonal abundance. Availability status of recorded 82 SIS fish was ranked as $39 \%$ Few, 23\% Common, 15\% Very Common, 16\% Rare and 7\% Very Rare (Fig. 4 and Table 1). Existence of some species like Danio devario, D. rerio, Osteobrama cotio, Badis badis, Chaca chaca, Silonia silondia were found at stake and recorded from specific one or two spot only.

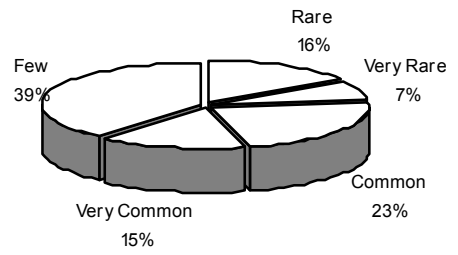

Fig. 4: Availability status of SIS fish in the Chalan Beel.

Seasonal Abundance: Seasonal variations in the abundance of the SIS fish was observed during the investigation period. M. vittatus, $M$. tengara, $P$. ticto, $P$. sophore, A. mola, L. guntea were found throughout the year abundantly. C. soborna, Chela sp. Salmostoma sp., and Chanda sp. were available in the post monsoon period when the water area started to decline. Whereas, species like Channa sp., A. testudineus, $H$. fossilis, $C$. batrachus, $N$. notopterus, A. coila, Colisa sp., N. nandus were found in highest amount in winter when the beel is mostly dried up. The rest of the species were available in the monsoon period.

The catch of SIS fish during the study period was highest in September-October and was lowest in February-March. The abundance of SIS fish increases with rainy season when the beel reaches maximum level, but in winter as water area declines, the fishes are easy to harvest. Hence it was observed that the maximum catch of SIS fish was in December. Karim (2003) reported that the abundance of fishes started to increase with rainy season and the pick harvesting season was in the late monsoon.

It was observed that the number of SIS fish varied in number, size and in kind at different sampling sites (Fig.5). The reason behind these variations depends on the basin topography, food availability and fishing intensity (Huda et al., 2009). At Mohisluti fish landing centre (Tarash, Sirajganj) the highest 79 species $(96.34 \%)$ of SIS fish were found during the investigation period. This landing centre is situated near the main water passing zone of Chalan Beel, in rainy season all aquatic animals pass through under the bridge no. 8 and 9 present on the Bonpara to Sirajganj highway toll road. At Singra, Chatmohor, Bhangura and Atrai fish landing centres, the total number of SIS fish observed was $75,74,73$ and 65 respectively.

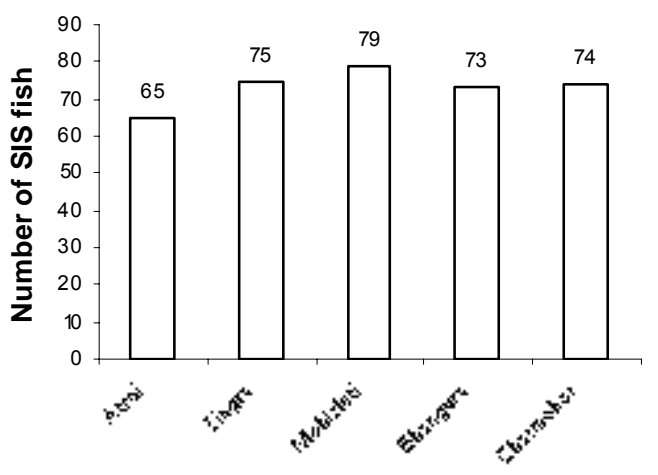

Fig. 5: The number of SIS fish found under different fish landing centres.

Existence of the SIS fish in Chalan Beel is at stake, due to over fishing and illegal fishing, which were found very common phenomena at the study spots. Small meshed fishing nets especially Current jal, Suti jal were found to be great problem for reducing SIS fish diversity in the Chalan Beel. In general illegal 
and over fishing using illegal fishing gears in Chalan Beel must be stopped. This will lead to increase the abundance of both the brood and juvenile fishes of this wetland. To sustainable development of SIS fish and to protect the species diversity, permanent and temporary fish sanctuaries should be established at different places in Chalan Beel. During the dry season this vast area is used for agriculture. Use of insecticides and other agro-chemicals became fatal for the aquatic fauna including the spawns and broods of indigenous fishes. So, there is a need to inform both the crop cultivators and the fishers about the effects of the hazardous chemicals on the fishes, other aquatic animals and human beings as well. Stocking of maternal fish for spawning, stock of quality fry and inclusion of poly-culture practices of small indigenous species may be an option for increasing abundance and diversity of these fishes, in return which will provide high nutrition at minimum cost to the nation.

\section{Conclusion}

The present result is an overview on the outstanding richness and diversity of Small Indigenous Species (SIS) of fish in the Chalan Beel. Community Based Management System would be taken to train the fishers and culturists to avoid using hazardous chemicals in the beel, and to avoid overfishing. Steps should also be taken to restrict fishing during the reproductive season of the fishes. As with the entry of flood water most of the SIS fishes start to breed, so fishing can be done keeping some definite restricted areas as the sanctuary for the brood and the spawns. These steps will increase the fish production of the Chalan Beel in future.

\section{References}

Amin, A.K.M.R., Parvez, I., Zaman, M.B. \& Amin, H.A. 2009. Study of the present status of Endangered small Indigenous species (SIS) of Fish in the Natural Waters of the North-West Part of Bangladesh, J. Environ. Sci. \& Natural Resources, 2(2): 163-168.

Backiel, T. \& Welcome, R.L. 1980. Guidelines for sampling fish in inland waters. EIFAC tech. Pap.33: 175.

Bhuiyan, A.L. 1964. Fishes of Dacca, The Asiatic Society of Pakistan, Publication No. 13, Dacca, pp. 148.

Felts, R.A., Rajts, F. \& Akhteruzzaman, M. 1996. Small Indigenous Fish Species Culture in Bangladesh. In: Development of Inland Fisheries Technical Brief. IFADP Sub-project 2. pp.41.

Hoq, E. 2006. Bangladesher Chhoto Mach; Published by Graphic Sign, 8 GKMC Shah Road, Chhto Bazar, Mymensingh 2200, p.20.
Hossain, M.A., Toyub, M.A., Islam, M.N. \& Hasan, M.R. 1994. Effect of species combination on the growth of major and Chinese carps in demonstration ponds under Feni district, Bangladesh J. Agril Sci. 21(2): 257-266.

Hossain, M.A.R., Nahiduzzaman, M., Sayeed, M.A., Azim, M.E., Wahab, M.A. \& Lin, P.G. 2009. The Chalan Beel in Bangladesh : Habitat and biodiversity degradation, and implications for future management. Lakes and Reservorirs : Research and Management, 14: 3-19.

Hossain, M.A. \& Afroze, S. 1991. Small fish as a resource in rural Bangladesh. Fish byte 9(2): 16-18.

Hossain, M.A., Afsana, K. \& Azad, A.K.M. 1999. Nutritional value of some small indigenous fish species (SIS) of Bangladesh. Bangladesh J. Fish. 3(1): 16-20.

Huda, A.T.M.N., Shah, M.S., Hasanuzzaman, A.F.M. \& Azam, M.R. 2009. An investigation on the ichthyofauna of the Gorai-Modhumati river system. Bangladesh J. Zool, 37(1): 11-24.

Jabbar, M.A. \& Karim, M. 1979. Economics of Alternative Technologies of Harvesting and Processing Marine Fish in Bangladesh. Bangladesh J. Agri. Eco., 11(1): 75.

Karim, M.S. 2003. Discussion on the causes of reduction of fisheries resources in Chalan Beel. In : Fisheries Fortnight (Matshaya Pakkhaya in Bengali). Department of Fisheries. Ministry of Fisheries and Livestock. Bangladesh. pp.95-96.

Kohinoor, A.H.M. 2000. Development of Culture Technology of three small indigenous fish- Mola (Amblypharyngodon mola), Punti (Puntius sophore) and Chela (Chela cahius) with notes on some aspects of their biology. Ph.D. Thesis. Department of Fisheries. BAU, Mymensingh.

Rahman, A.K.A. 1989. Freshwater fishes of Bangladesh. Zoological Society of Bangladesh, Department of Zoology, University of Dhaka. Dhaka- 1000, pp.264.

Rahman, A.K.A. 2005. Freshwater fishes of Bangladesh. $2^{\text {nd }}$ edition, Zoological Society of Bangladesh, Department of Zoology, University of Dhaka. Dhaka1000, pp. 263.

Talwar, P.K. \& Jhingran, A.G. 1991. Inland fishes of India and adjacent countries, Vol. 1 and 2, Oxford \& IBH Publishing Company Pvt. Ltd., New Delhi, pp.1158.

Thilsted, S.H., Ross, N. \& Hasan, N. 1997. The role of small indigenous fish species in food and nutrition security in Bangladesh, NAGA News letter, Jul - Dec. $13 \mathrm{pp}$.

Uddin, M.J. 2002. The Agricultural potentiality of wetlands: A case study of the Chalan Beel Areas of Bangladesh. Dhaka Univ. J. Biol. Sci. 11(2): 139-145.

Villif, A. \& Jorgensen, L.B. 1993. Analysis of naeringgsstoffat I, in An Environmental Monitoring System for GOLDA project: CARE - Bangladesh Interim Report. 